SYLLECTA CLASSICA 22 (2011): 95-111

\title{
PLUTARCH AND SAINT BASIL AS READERS OF GREEK LITERATURE
}

\author{
JEFFREY BENEKER
}

\begin{abstract}
Basil's Address to Young Men on How to Read Greek Literature is often read as an imitation of Plutarch's How to Study Poetry. Exploring the authors' connections more generally, I suggest that Basil has relied on Plutarch's approach in both the Moralia and the Lives to make the central argument of his essay, which is a justification for the reading of pagan literature in a Christian context. Basil follows Plutarch in his moralizing interpretations of historical anecdotes and in turning to Plato's Republic for philosophical support, but he also adapts Plutarch's approach to fit the social, religious, and political climate of his times.*
\end{abstract}

The Address to Young Men on How to Read Greek Literature, written by Basil, Bishop of Caesarea, probably in the 370s, has often been compared with works by Plutarch, to find a model for the essay and to suggest general Plutarchan influence on Basil's thought and writing. Olga Alieva has summarized the history of this comparison in a paper recently delivered in Moscow. As Alieva shows, some scholars have concluded that Basil was borrowing directly from Plutarch, while others have found the evidence for Plutarch's influence more ambiguous. Max Pohlenz, for instance, argues that Basil drew directly from Plutarch's Progress in Virtue (Prof. in virt.), while Ernesto Valgiglio and Mario Naldini argue for the fundamental influence of Plutarch's similarly-themed essay How to Study Poetry (De aud. poet.). Valgiglio, however, also finds in Basil an independence of form and spirit, and Naldini mentions originality in interpretation, especially as related to Basil's discussion of what is profitable,

\footnotetext{
* I am very grateful to Noreen Humble for her advice and for sharing with me her forthcoming work on Plutarch in Byzantium. I would also like to thank the editor for helpful criticism and suggestions.
} 
or $\chi \rho \eta \dot{\sigma} \mu \mathrm{ov}$, in pagan literature. ${ }^{1} \mathrm{~N}$. G. Wilson takes a more analytical tack, admitting that he is not in fundamental disagreement with Pohlenz (he wrote before Valgiglio and Naldini), but nevertheless claiming not to have found "enough verbatim similarities to prove with ... certainty that Basil was borrowing directly from Plutarch" (12). Even so, Wilson's commentary identifies twenty points of contact between Basil's text and the works of Plutarch, including similarities in vocabulary and phrasing, shared literary references, and common anecdotes about historical figures. ${ }^{2}$

Because of their shared themes and similarity of argument, Plutarch's How to Study Poetry has sometimes been read in conjunction with Basil's essay. In 1902 Frederick Padelford published English translations of the two essays in a single book, along with interpretive and comparative introductions. He notes in his preface that the essays had been paired as early as 1600, singling out the 1694 edition published at Oxford by the future Archbishop of Canterbury (8). In this article I also compare these two essays, following the lead of Valgiglio and Naldini, however, by taking into account the spirit and the form of the essays rather than focusing on verbatim borrowings from Plutarch in Basil's text. My aim is to compare the authors' approaches to the fundamental problem that motivates both essays, namely, how to justify the reading of literature (for Plutarch, that means Greek poetry, while Basil also includes prose works and speeches), when that literature is judged to be inferior to and even at odds with philosophy, in the case of Plutarch, or with Holy Scripture, in the case of Basil. While Basil probably turned to Plutarch for some of his anecdotes and even for some of his arguments, as Alieva's survey shows, in what follows I demonstrate that both authors also draw upon different passages from Plato's Republic in order to frame the problem of reading Greek literature, and they justify this reading by claiming that it serves as preparation for more advanced study. Making use of examples from Plutarch's Lives as well as How to Study Poetry, I conclude that it is the authors' like-minded, moralizing approach to Greek literature that is most responsible for the similarities between the two essays. ${ }^{3}$

\footnotetext{
${ }^{1}$ See Alieva $1-2$.

${ }^{2}$ See also Boulenger 28-29, Pastorino, La Matina 84, and Hunter and Russell, who call Basil's essay an imitation of Plutarch's How to Study Poetry (2).

${ }^{3}$ For an examination of Plutarch's influence on early Christian authors, including Basil, see La Matina, who provides further bibliography. For Plutarch's influence on
} 
I will begin by examining the introductions to the essays, to consider the authors' own statements about who their readers are and why they are writing. Plutarch addresses his essay on the study of poetry to Marcus Sedatus, who has a son, Cleander, about the same age as Plutarch's son, Soclarus. Although he does not provide exact ages, Plutarch says that it would not be possible to keep the boys from studying poetry, implying, as Richard Hunter writes, that they are "beyond 'elementary schooling"" and, in modern terms, "young adolescents" (169 n. 1). Thus they are ready to move ahead in their education with the serious reading of poetic literature. This is an urgent matter, according to Plutarch, because the young men might well need more oversight in their reading than they need when out on the streets (15a). Poetry can be dangerous because it presents fictional stories that are pleasant to hear, and therefore young students might read it indiscriminately and only for enjoyment, without concern for discovering anything that is true or otherwise valuable within the fiction. But rather than address this danger by eradicating poetry altogether from his son's curriculum, Plutarch advises Sedatus to seek out works of poetry that have beneficial, philosophical themes, and then to reject everything else (15f).

This is really the crucial point in Plutarch's justification for his essay, namely that reading poetry is not an end in itself:

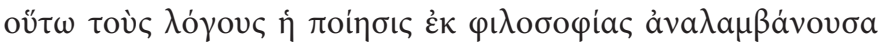

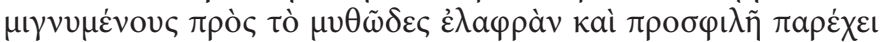

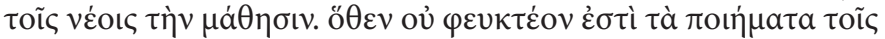

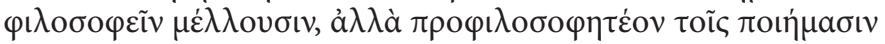

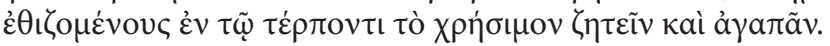

Thus poetry, by taking up its themes from philosophy and blending them with fable, renders the task of learning light and agreeable for the young. And so those who are intending to pursue philosophy should not avoid poetry, but they should use poetry as an introductory exercise in philosophy by training themselves habitually to seek out and to be fond of what is profitable in pleasure $(15 \mathrm{f}-16 \mathrm{a}) .{ }^{4}$

Byzantine literature in general, see Humble (forthcoming a), who shows that his works were known sporadically from the fourth century but appear to have enjoyed wide appeal and influence particularly beginning in the tenth century.

${ }^{4}$ Text of Plutarch's How to Study Poetry is from Babbitt; text of the Lives comes from the Teubner editions. Text of Basil's essay is from Boulenger as corrected by Wilson. All translations are my own. 


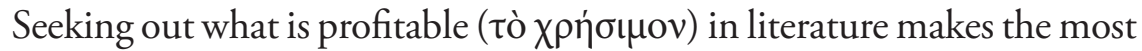
obvious connection between the essays of Plutarch and Basil. Before turning to the Bishop of Caesarea, however, I would like to consider an unspoken component to Plutarch's argument. Plutarch makes his case for reading literature in opposition to the idea that one should reject all poetry because some of it is dangerous. Lurking behind this opposition is likely to be the decision of Plato to ban poets from his fictitious city in the Republic, and by extension, to keep poetic influences away from the training of the human soul. ${ }^{5}$ Now, in the third book of the Republic where Socrates states that he will ask poets to leave the city (398a), Plato is primarily interested in keeping the guardian class from becoming imitators of base men, as actors and singers of epic poetry are required to be when performing. ${ }^{6}$ But when he returns to the question of poetry in the tenth book, he is concerned about both imitation and the influence of performances on the audience. Socrates consents to giving poetry the chance to defend itself, but he also shows his skepticism by warning that "there is an ancient quarrel between poetry and philosophy" ( $\pi a \lambda a i \alpha$

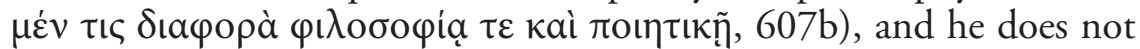
really expect that poetry will acquit itself. He will allow it to return to his city, however, if its defenders can show "that it is not only pleasurable but also beneficial both to constitutions and to human life" ( $\dot{\omega} \varsigma$ ov̉

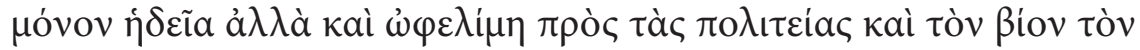

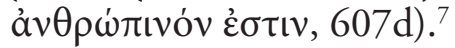

Scholars have interpreted the nature of the "ancient quarrel" mentioned by Socrates in various ways, but in general it must refer to the fact that poets and philosophers take different approaches to questions about political constitutions and human life. And regardless of what it might mean in the narrow context of Socrates' argument in the Republic, Plutarch and other later readers would surely have interpreted it within the wider context of Plato's fully developed philosophy. In a recent overview and reinterpretation of this quarrel, Glenn Most writes that, "From the early Ion through the more mature Symposium, Phaedrus, and

\footnotetext{
${ }^{5}$ Cf. Hunter and Russell 79.
}

${ }^{6}$ Resp. 392c-398b; cf. White 97; Reeve 220-26.

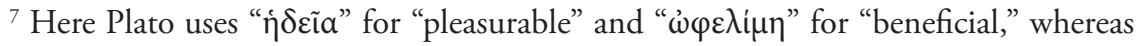

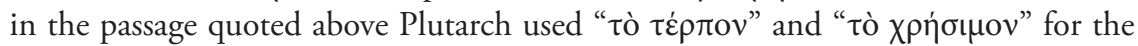
corresponding nouns. Text of the Republic is from Slings. 
Republic, until the late Laws — to mention only these dialogues-Plato's own quarrel with the poets is well established, deep-rooted, persistent, recurrent, explicit, and intense." ${ }^{8}$ Plutarch would have been keenly aware of Plato's various arguments for the danger to be found in poetry, and in considering the Republic in particular, he could have recalled the narrow criterion for allowing poetry back into the curriculum. ${ }^{9} \mathrm{He}$ responds to this resistance by assuring Sedatus that he is advocating a very careful management of their sons' educations:

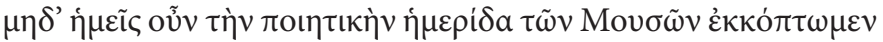

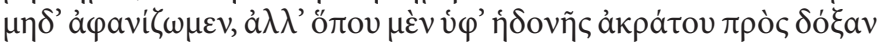

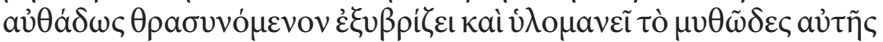

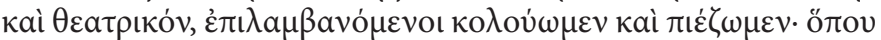

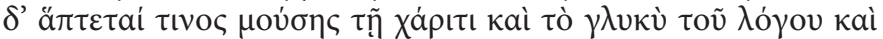

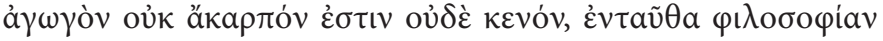

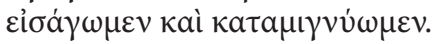

Let us not cut out or destroy the Muses' poetic vine, but wherever the fabulous and dramatic part, being boldly encouraged toward glory because of immoderate pleasure, becomes insolent and runs riot, let us gain control over it by pruning and pressing it back. But wherever the sweetness of speech touches upon sophistication through grace and as a guide is neither fruitless nor empty, let us bring in philosophy and mix it with the poetry (15f).

Plutarch, willing to heal the ancient quarrel between poetry and philosophy, nonetheless will keep the dramatic and fabulous elements of poetic performance in check, acknowledging, it seems, Plato's special concern for the harm done when actors or singers imitate men of poor character or performers of bad deeds.

Basil tackles a similar problem in the introduction to his essay, seeking to allay the fears not of Platonists in this case, but of Christians who would object to the pagan values transmitted along with Greek literature. He responds to the presumed criticism in two ways. First, he takes a selective approach very similar to Plutarch's, though in place of

\footnotetext{
${ }^{8}$ Most 2. See also Walker 294-302; Hunter 175-77; Barfield 10-31; Hunter and Russell 2-17.

9 For the influence of Plato's Republic, Protagoras, and Laws on Plutarch's view of poetry in this essay, see Hunter and Russell 2-9. On Plutarch's Platonism in general, see Jones; Dillon 184-230; Opsomer.
} 
the vinedresser, pruning the bad and encouraging the good, Basil turns to the ship's pilot for his analogy:

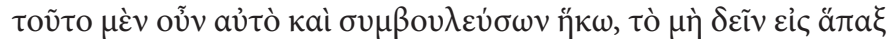

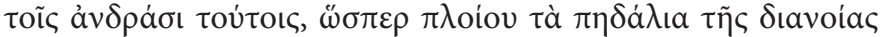

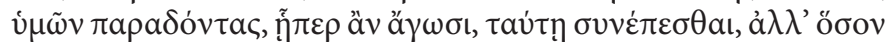

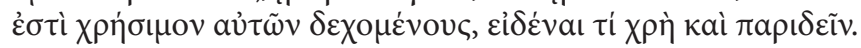

This is precisely the advice that I have come to share with you: that you should not once and for all hand over the rudders of your mind, as of a ship, to these [pagan authors] and to follow them wherever they may lead, but accepting from them whatever is profitable, you should also know what to overlook (1.24-28).

The imagery of the ship might be inspired by Plutarch, who often

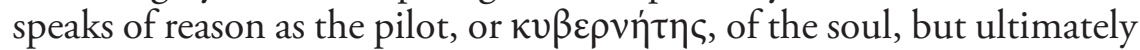
it comes from Plato. ${ }^{10}$ In fact, the phrase used here, "handing over the rudders of your mind, as of a ship," is almost certainly borrowed from the Clitophon. ${ }^{11}$ But this phrase might also have been inspired by, and so remind the knowledgeable reader, of a passage from the Republic, making Basil's analogy richer and linking him even more generally to the Platonic tradition with which Plutarch also engaged. In book 6 of the Republic, Plato has Socrates compare the treatment received by a philosopher at the hands of his fellow citizens to the selection of a pilot

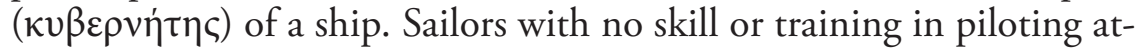
tempt to persuade the ship's owner to turn the rudder $(\pi \eta \delta \dot{\alpha} \lambda \iota \mathrm{ov})$ over to them, claiming that the one who succeeds in this persuasion is "a sailor, good at steering, and an expert about sailing" (vavtıkòv ... kaì

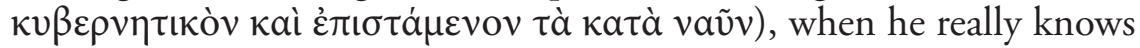
nothing at all about being a pilot, while the one who is not successful in persuading the ship's owner but is nonetheless best suited to be the pilot because of his wisdom, they call "unprofitable" (ä $\chi \eta \eta \tau \tau v, 488 a-489 a)$. The sailors, of course, are not wise enough themselves to recognize the

${ }^{10}$ In How to Study Poetry, Plutarch refers to education in general as traveling on the

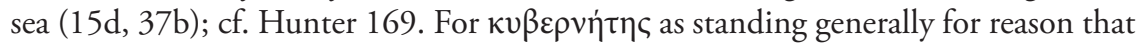
governs the soul in Plutarch, see Beneker 46-48.

${ }^{11}$ At 408b2, Plato has Clitophon argue that it is better for a person to live as a slave than as a freeman, "having turned over the rudders of the mind, as of a ship, to someone else

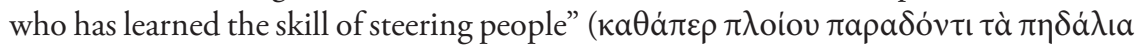

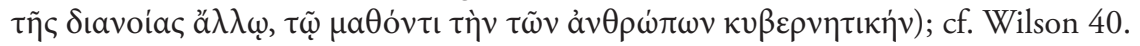


man who in fact possesses the wisdom to be the ship's true pilot, just as the average citizen in a city cannot perceive the wisdom or political skills of the philosopher. If we recall this passage from the Republic while reading Basil's admonition, then we can see that he is warning his nephews not to give in to the persuasion of the crowd of Greek authors, who might be appealing because their works give pleasure, but who in reality have nothing of value to offer. Rather, they should be discriminating, seeking out the works of those authors who are truly wise because they illustrate virtue.

Basil returns to this point in section 6 of his essay, once he has established that learning about virtue is the thing that is profitable ( $\chi \rho \eta \dot{\sigma} \mu \mathrm{ov})$ in reading Greek literature:

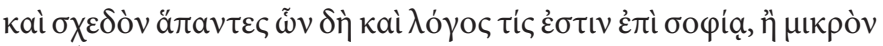

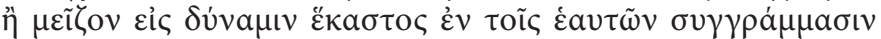

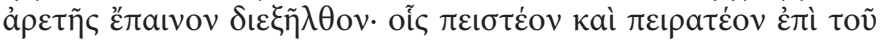

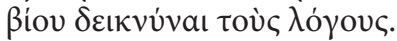

And nearly all [writers] who have some reputation for wisdom have recounted a praise of virtue in their works to a greater or lesser extent, depending on their ability. We must trust in these writers and attempt to demonstrate their words in the way we live (6.1-4).

Basil goes on to emphasize the importance of making virtue real, and he concludes this portion of his argument with what might be a double reference to the third book of the Republic. First, he says that the person who has not internalized virtue "will pursue the appearance of being

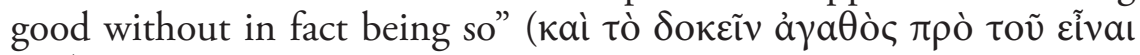
$\delta เ \omega \dot{\xi} \varepsilon \tau a l, 6.24)$. Here he seems to be loosely quoting a sentiment from

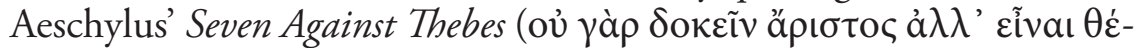
$\lambda \varepsilon \mathrm{l}, 592)$, which has been filtered through Plato, who names Aeschylus

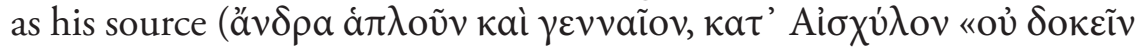

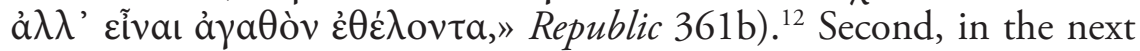
sentence Basil cites Plato by name, borrowing the assertion that to seem just while not being so is the extreme of injustice ( $\dot{a} \lambda \lambda^{\prime}$ o ovंós $\dot{\varepsilon} \sigma \tau \mathrm{\tau}$

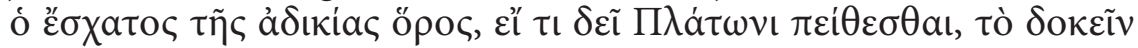

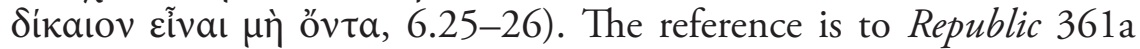

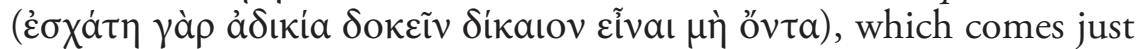
before Plato's quotation of Aeschylus.

${ }^{12}$ Cf. Wilson $56-57$. 
Basil, then, has Plato very much in mind as he establishes his theme and lays the groundwork for his argument. If he has been inspired by Plutarch's essay, then he appears to have looked not simply to its form, but also to have followed Plutarch's lead in turning to Plato as he considered the problem of selecting the right readings from the great corpus of Greek literature. It seems likely to me, in fact, that both Basil and Plutarch are sailing the same sea (to continue the analogy) and engaging with a larger dialogue about how and why philosophers should read literature. The Platonic foundation of this dialogue would have been well known to both of them, and Plutarch might have served as an inspiration or a model of how to approach this ancient and fraught question.

Plutarch's approach might also have shaped the second element of Basil's response to his presumed critics. Another implied question that Plutarch addresses in his introduction may be phrased something like this: even if there is philosophical value in some poetry, why bother with this dangerous game of finding it among all sorts of empty pleasures when you can simply read philosophy directly? In response, Plutarch argues that poetry softens philosophy and, because it contains philosophical principles in an easier-to-understand form, serves as an introductory exercise in philosophy, or "pre-philosophy," for young students: $\pi \rho \circ \varphi$ -

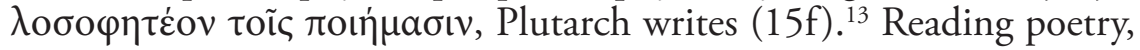
therefore, trains young men in philosophical principles and teaches them to seek out what is useful in what is pleasant. ${ }^{14}$ As Hunter puts it, Plutarch is advising that the young reader "be actively engaged in the reading process in a manner which prepares [him] for the cut and thrust of philosophic debate" (172). Basil takes a similar approach, although he is rebutting a slightly different hypothetical question: why read pagan literature when we have Holy Scripture? His answer, however, is essentially the same. The study of Greek literature is not a replacement for the study of Scripture, but it serves as preliminary training for that later and more challenging endeavor:

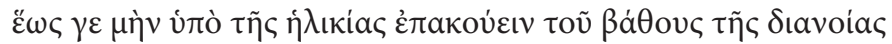

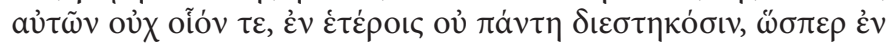

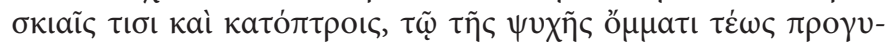

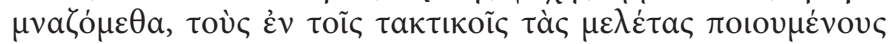
$\mu$ ноú $\mu \varepsilon v o$.

${ }^{13}$ See the full passage quoted above, p. 97.

${ }^{14}$ Plutarch returns to this point in the essay's conclusion (36d-e); cf. Hunter 169-70. 
So long, then, as it is not possible due to your age to grasp the depth of the meaning [in the Scriptures], with the aid of the other writings, which are not entirely different, as if with the aid of shadows and mirrors, we must in the mean time do preliminary exercises for the eye of the soul, imitating those who practice military maneuvers $(2027-31){ }^{15}$

In both essays, the assertion that reading Greek literature is a preliminary exercise must be made at the outset; otherwise the whole argument for the philosophical value of this literature becomes unnecessary. Furthermore, the idea of engaging in preliminary exercises as preparation for more advanced study is likely to have seemed quite natural to Basil, who himself might have been educated through rhetorical progymnasmata while studying as a young man under Libanius. ${ }^{16}$

If it is true that Basil followed Plutarch's approach without verbatim borrowing or strict imitation, we might have an explanation for a minor but rather curious difference between the essays. Plutarch addresses his advice for studying poetry, as I have said, to Marcus Sedatus. This seems entirely logical, since the young Cleander's education would be carried out under the supervision of his father, and indeed, careful supervision is just what Plutarch advocates. Basil is similarly concerned with the education of his nephews, but rather than address his argument to their parents, he writes to the young men directly. The boys' ages, conjectured to be fifteen to sixteen years old, present something of a problem, since many of the literary references in the essay assume quite a lot of reading already in Greek literature, not only in standard authors, such as Homer and Hesiod, who might be encountered early in one's schooling, but also

${ }^{15}$ By "the aid of shadows and mirrors" Basil is probably referring to the indirect observation of the truths that young men will eventually observe directly in Scripture. Plutarch uses the analogy of the mirror at Progress in Virtue 85a-b and Aemilius 1.1 (see below) to refer to the observation of the character of historical figures via reading. Cf. Pelling, who explains that in the Aemilius Plutarch is suggesting that his readers "explore the experiences and dilemmas of those figures from the past, and ask what we would have done ourselves in their circumstances, or what they would have done in ours" (17); see Pelling's n. 37 for further bibliography.

${ }^{16}$ Libanius has left the largest collection of these preliminary rhetorical exercises and might have been the author of the treatise on progymnasmata that is usually ascribed to Hermogenes; see Kennedy 58-59; Gibson xx-xxv. For the influence of rhetoric on Basil's theological writings, see Kustas. 
in more "advanced" authors such as the sophist Prodicus. "This argues," Wilson writes, "a considerable degree of knowledge [in the young men], if not downright precocity" (8). This considerable degree of knowledge might indicate that Basil was, in fact, addressing the boys' parents indirectly, and intending to reach other adult readers as well. Although his thesis is narrowly focused on education, this larger audience might well have needed convincing about the general value, and even the safety, of pagan literature only a decade or so after the brief reign of Julian, the apostate emperor. Julian himself had studied pagan Greek authors in a Christian environment as a youth. Thus he might have been a symbol of the danger that Basil seeks to mitigate. ${ }^{17}$ In any case, if Basil followed Plutarch's example even to a small degree, he would not have left oversight of the critical and risky process of selection to the boys themselves. ${ }^{18}$ It seems that direct address to the boys' parents might not have been well received, and so this might be the reason, perhaps deriving ultimately from political necessity, for Basil's addressing his argument to the young men instead.

Turning from the framing of the problem to the authors' general approach to the reading of literature, we notice how the two are again like-minded. Here I would like to broaden the comparison to include Plutarch's Lives. In the introduction to the Aemilius Paulus, Plutarch claims that he began to write his biographies for the sake of others, but that he is continuing the series for himself, since he enjoys the effort of trying to arrange his life according to the virtues demonstrated by historical figures:

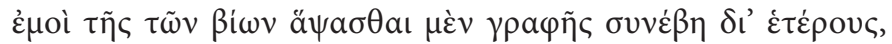

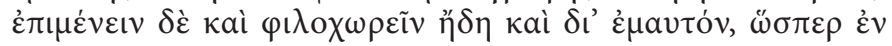

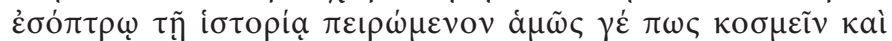
à $\varphi$ o

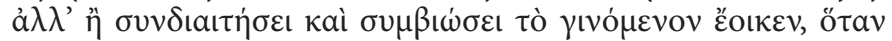

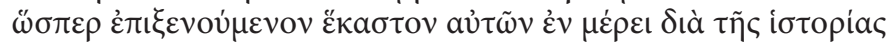

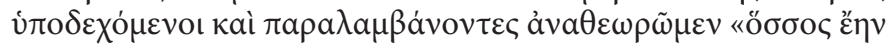

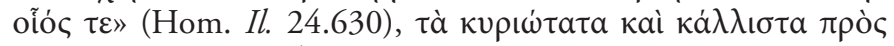
$\gamma \nu \tilde{\omega} \sigma \nu v a ̉$ à $\tau \tilde{\omega} \nu \pi \rho \dot{\xi} \xi \varepsilon \omega \nu \lambda \alpha \mu \beta \alpha \dot{\alpha} \nu o v \tau \varepsilon \varsigma$.

${ }^{17}$ On the date of Basil's essay, see Wilson 9; Naldini 16-17. On Julian's education in Greek literature, see Browning 34-39; Bowersock 23-24.

${ }^{18}$ Cf. Hunter 174, on Plutarch: "Although the discussion of poetry will indeed sharpen the young man's desire and aptitude to question, there is no suggestion that he is free to interpret outside the strict parameters with which he will be supplied by his teachers." 
I happened to undertake the writing of these lives for the sake of others, but now I am continuing and enjoying them for my own sake. As if looking into a mirror (in some way or other), I try to use my investigation to give order to my life and to shape it according to the virtues of these men. For this experience is just like keeping a daily routine and living with them, whenever I welcome and receive each one of them in turn through my investigation, as if receiving a guest, and I observe "how great and of what character" each man is, deriving from his deeds what is most important and finest to know (1.1-2).

Basil expresses a similar sentiment, as part of his argument that reading Greek literature (of all types, not simply poetry) is critical to the preliminary training that later allows one to understand Holy Scripture:

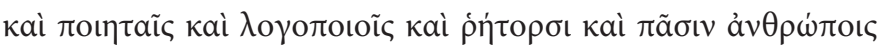

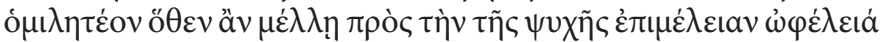

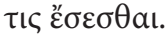

One must keep company with poets, prose writers, and orators, and with all men from whom one may find some benefit when it comes to the care of the soul (2.37-39).

Although Basil here focuses on the authors, he clearly has "kept company" with the characters from literature and history as well. For instance, he recounts anecdotes about Odysseus (4.10-11, 5.25-42), Pericles (7.9-11), and Polydamus, an Olympic athlete (8.22-24), in addition to quoting from such authors as Plato, Prodicus (5.55-77), and Euripides (6.22-24).

An anecdote about Alexander the Great creates another point of comparison between the two authors, showing again how Plutarch and Basil sailed the same interpretive sea. In the Alexander Plutarch relates the story of how the Macedonian king behaved with great moderation after capturing the wife and daughters of the Persian king, Darius, despite their exceptional beauty. He relates the story so as to make Alexander's self-control fundamental to his identity as king:

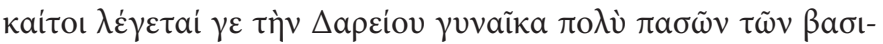

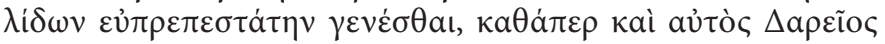

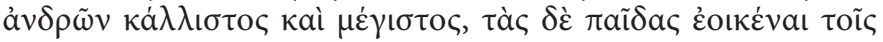

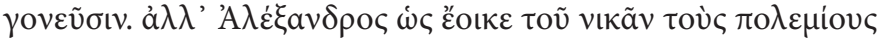

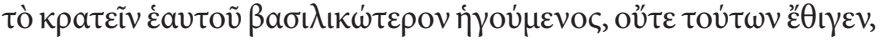

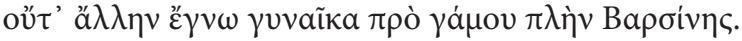


And yet it is said that Darius' wife was by far the most attractive of all the royal women, just as Darius himself was the finest and tallest of the men, and that his daughters took after their parents. But Alexander, as it seems, believed that it was more king-like to master himself than to conquer his enemies, and so he neither touched these women, nor was he intimate with any other woman before marriage, except for Barsine (21.6-7).

In framing the anecdote in this way, Plutarch connects his portrait of Alexander to Classical Greek notions about the intersection between a statesman's private, personal behavior (especially his ability to exercise self-restraint), and his public, political success. ${ }^{19}$ Xenophon, for instance, expresses a similar sentiment in his encomium of Agesilaus, praising the Spartan king for acknowledging the danger in accepting a young man's kiss and remarking that "I am quite sure, however, that many more men are able to master their enemies than to master such desires

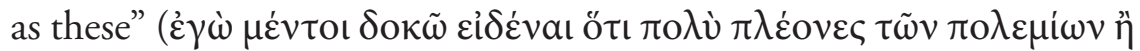

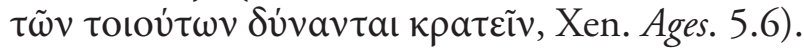

Basil also invokes the example of Alexander, reading it in essentially the same way as Plutarch and drawing a similar conclusion. In the spirit of his argument, which conceives of such anecdotes as preliminary to the study of Scripture, Basil goes on to make the connection to Christian teaching overtly:

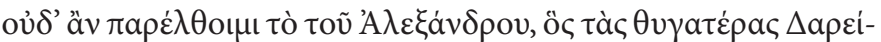

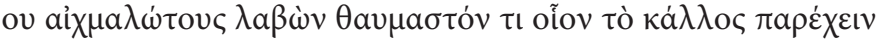

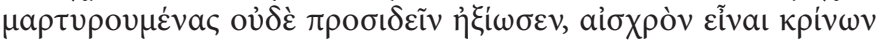

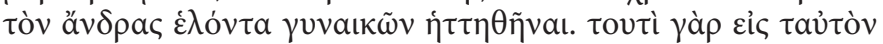

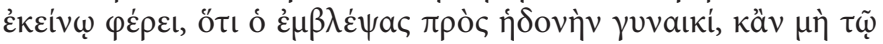

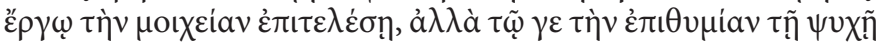

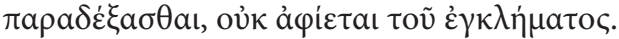

Nor should we pass by the story of Alexander, who took the daughters of Darius prisoner and, although they were reported to exhibit an amazing beauty, he did not think it right to look upon them. Rather, he judged it to be a shameful thing for a man who had conquered other men to be defeated by women. For this amounts to the same thing as in that saying, that the one who has looked upon a woman with pleasure has committed adultery, even if he has not acted, but because he has admitted desire into his soul, he is guilty of the crime (7.40-47).

${ }^{19}$ For Classical attitudes, see e.g. Dover 208; Davidson 250-308. 
"That saying" comes from the Gospel of Matthew (5.28). The notion of a crime is, of course, part of Judeo-Christian ethics, but Plutarch (and Plato and Xenophon, too, for that matter) would have acknowledged the transgression that lies behind the guilt: allowing $\dot{\varepsilon} \pi \imath \theta v \mu$ ia free reign is something that must be guarded against. For Basil, this element of the anecdote is solidly based in Scripture, since in Matthew the crime also results from looking upon a woman with desire:

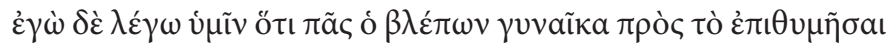

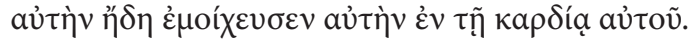

And I say to you that anyone who looks upon a woman so as to desire her has already committed adultery with her in his heart (Mat. 5.28).

Both authors' use of this anecdote, then, neatly demonstrates the ethical connection between pagan and Christian thought that Basil found so valuable, and we may observe how their like-minded reading of the same literature has led to similar conclusions. Plutarch's interpretation of this anecdote might have been appealing to Basil, and Plutarch might even have been his source. ${ }^{20}$ Even so, Basil's effort to give the anecdote a particularly Scriptural, Christian interpretation shows that he is grappling with a problem common to other Byzantine writers. In her study of the Anacreontic poems by John of Gaza, for instance, Frederica Ciccolella argues that John turned to allegory in order to circumvent "the ethical rejection of myth promoted by Neoplatonism and Christianity." This allegorical interpretation, she argues, "was a way of keeping the study of pagan literature alive in a Christian background" (94-95). ${ }^{21}$ While not relying on allegory in his reading of the anecdote about Alexander, Basil nonetheless adapts (or updates) the earlier, pagan interpretation of Alexander's self-restraint so that it matches the expectations of his contemporary, Christian audience.

In conclusion, I would like to quote part of a short, eleventh-century Byzantine poem by Johannes Mauropus, written well after Basil's time but expressing a sentiment which, given his adaptation of Plutarchan

\footnotetext{
${ }^{20}$ See Valgiglio 77; Naldini 192.

${ }^{21}$ On the date of John of Gaza, see Cameron. For Basil's relationship to Neoplatonism, see Rist.
} 
and Platonic ideas to Christian theology, the Bishop of Caesarea probably would have endorsed:

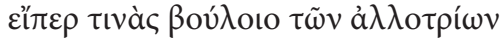

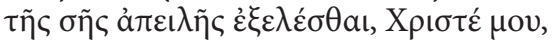

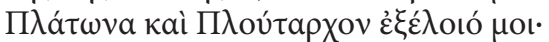

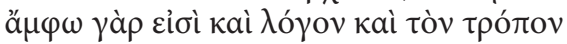

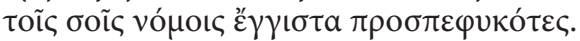

If you should wish to exempt anyone among the pagans from your punishment, my Christ, may you exempt for me Plato and Plutarch. For both of these men clung most closely to your laws in their thought and their manner. ${ }^{22}$

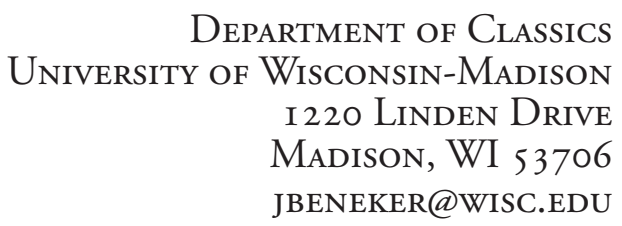

${ }^{22}$ For the full text, see Trypanis. See Humble (forthcoming a) and (forthcoming b) on the general compatibility between Plutarch's ethics and the Christian values of Byzantine writers, and also for the possible influence of his Lives on the form of historical writing in the tenth century. 


\section{Works Cited}

Alieva, O. “On Plutarch's Influence upon St. Basil's Address to the Young on the Value of Greek Literature.” Paper delivered at XX Theological Conference at PSTGU, Moscow, 2009. Made available at http://academia.edu.

Babbitt, F. C. Plutarch's Moralia in Sixteen Volumes. Vol. I. Loeb Classical Library 197. Cambridge, MA: Harvard University Press, 1927.

Barfield, R. The Ancient Quarrel between Philosophy and Poetry. Cambridge: Cambridge University Press, 2011.

Beneker, J. The Passionate Statesman: Eros and Politics in Plutarch's Lives. Oxford: Oxford University Press, 2012.

Boulenger, F. Saint Basile: Aux jeunes gens sur la manière de tirer profit des lettres helléniques. Paris: Société d'Édition «Les Belles Lettres», 1965.

Bowersock, G. W. Julian the Apostate. Cambridge, MA: Harvard University Press, 1978.

Browning, R. The Emperor Julian. London: Weidenfeld and Nicolson, 1975.

Cameron, A. "On the Date of John of Gaza.” CQ n.s. 43 (1993): 348-51.

Ciccolella, F. "'Swarms of the Wise Bee': Literati and Their Audience in Sixth-century Gaza." In Approches de la troisième sophistique: hommages à Jacques Schamp, edited by E. Amato, A. Roduit, and M. Steinrück, 80-95. Collection Latomus 296. Brussels: Editions Latomus, 2006.

Davidson, J. Courtesans and Fishcakes: The Consuming Passions of Classical Athens. London: Harper Collins, 1997.

Dillon, J. M. The Middle Platonists: 80 B.C. to A.D. 220. Ithaca, NY: Cornell University Press, 1977. Revised with a new afterword, 1996.

Dover, K. J. Greek Popular Morality in the Time of Plato and Aristotle. Oxford: Blackwell, 1974.

Gibson, C. A. Libanius's Progymnasmata: Model Exercises in Greek Prose Composition and Rhetoric. Atlanta: Society of Biblical Literature, 2008.

Humble, N. "Plutarch in Byzantium." In Cambridge Companion to Plutarch, edited by F. Titchener and A. Zadorozhnyy. Cambridge: Cambridge University Press, forthcoming (a).

. "Imitation as Commentary? Plutarch and Byzantine Historiography in the 10th Century." In Acts of the Ninth International Congress of the International Plutarch Society, Ravello, 2011, edited by P. Volpe Cacciatore. Naples: D'Auria, forthcoming (b). 
Hunter, R. L. "Reading for Life: Plutarch, 'How the young man should study poetry."” In Critical Moments in Classical Literature: Studies in the Ancient View of Literature and its Uses, 169-201. Cambridge: Cambridge University Press, 2009.

Hunter, R. L. and D. Russell. Plutarch: How to Study Poetry (De audiendis poetis). Cambridge: Cambridge University Press, 2011.

Jones, R. M. The Platonism of Plutarch. Menasha, WI: George Banta, 1916.

Kennedy, G. A. Greek Rhetoric under Christian Emperors. Princeton, NJ: Princeton University Press, 1983.

Kustas, G. L. "Saint Basil and the Rhetorical Tradition." In Basil of Caesarea: Christian, Humanist, Ascetic. A Sixteen-hundreth Anniversary Symposium, edited by P. J. Fedwick, 221-79. Toronto: Pontifical Institute of Mediaeval Studies, 1981.

La Matina, M. "Plutarco negli autori cristiani greci." In L'eredità culturale di Plutarco dall'antichità al Rinascimento: Atti del VII Convegno plutarcheo Milano-Gargnano, 28-30 maggio 1997, edited by I. Gallo, 81-110. Naples: D’Auria, 1998.

Most, G. "What Ancient Quarrel between Philosophy and Poetry?" In Plato and the Poets, edited by P. Destrée and F.-G. Herrmann, 1-20. Mnemosyne Supplements 328. Leiden and Boston: Brill, 2011.

Naldini, M. Basilio di Cesarea: Discorso ai Giovani. Biblioteca Patristica. Florence: Nardini Editore, 1984.

Opsomer, J. "The Place of Plutarch in the History of Platonism." In Plutarco e la cultura della sua età: Atti del X Convegno plutarcheo, Fisciano-Paestum, 27-29 ottobre 2005, edited by P. Volpe Cacciatore and F. Ferrari, 283-309. Naples: D’Auria, 2007.

Padelford, F. M. Essays on the Study and Use of Poetry by Plutarch and Basil the Great. Yale Studies in English 15. New York: Henry Holt, 1902.

Pastorino, A. "Il Discorso ai giovani di Basilio e il De audiendis poetis di Plutarco." In Basilio di Cesarea: la sua età, la sua opera e il basilianesimo in Sicilia: Atti del Congresso internazionale, Messina, 3-6 XII 1979, 217-57. Messina: Centro di studi umanistici, 1983.

Pelling, C. Plutarch: Caesar, Translated with an Indroduction and Commentary. Oxford: Oxford University Press, 2011.

Pohlenz, M. Review of G. Büttner, Basileios des Grossen Mahnworte an die Jugend (Munich: Würzburg Dissertation, 1908). Berliner philologische Wochenschrift 31 (1911): cols. 180-82.

Reeve, C. D. C. Philosopher-Kings: The Argument of Plato's Republic. Princeton, NJ: Princeton University Press, 1988.

Rist, J. M. "Basil's 'Neoplatonism': Its Background and Nature." In Basil of Caesarea: Christian, Humanist, Ascetic. A Sixteen-hundreth Anniversary Symposium, edited by P. J. Fedwick, 137-220. Toronto: Pontifical Institute of Mediaeval Studies, 1981. 
Slings, S. R. Platonis Rempublicam. Oxford: Oxford University Press, 2003.

Trypanis, C. A. The Penguin Book of Greek Verse. London: Penguin Books, 1971.

Valgiglio, E. "Basilio Magno Ad adulescentes e Plutarco De audiendis poetis." Rivista di Studi Classici 23 (1975): 67-86.

Walker, J. Rhetoric and Poetics in Antiquity. New York: Oxford University Press, 2000.

White, N. P. A Companion to Plato's Republic. Indianapolis: Hackett Publishing Company, 1979.

Wilson, N. G. Saint Basil on the Value of Greek Literature. London: Gerald Duckworth, 1975. 